\title{
The role of recent tectonics and hydrological processes in the evolution of recurring landslides on the Danube's high bank in Dunaföldvár, Hungary
}

\author{
Gyula Mentes* \\ Geodetic and Geophysical Institute, Research Centre for Astronomy and Earth Sciences, Hungarian Academy of Sciences, Csatkai E. u. 6-8., H-9400 Sopron, Hungary
}

\section{A R T I CLE INFO}

\section{Keywords:}

Ground water

Landslide

River water level

Tilt

\begin{abstract}
A B S T R A C T
There are high loess banks prone to landslide along the River Danube in Hungary. One of these is the high loess bank in Dunaföldvár, where several landslides occurred in the last decades. Quantitative relationships between the movements of the high loess bank and the variation of the water level of the River Danube, the ground water table, precipitation and temperature are investigated by two borehole tiltmeters and a vertical borehole extensometer. The twelve-year long observation from 2002 to 2014 made it possible to distinguish between the high bank movements due to slow recent tectonic and geomorphologic processes and the short-period (from hours to months) movements caused by hydrometeorological effects. The results revealed that besides geomorphologic processes recent tectonics can play an important role in the recurrence of landslides in the area. In the investigated period the total tilt of the high bank was $162 \mu \mathrm{rad}$ in the SSE direction according to the geomorphologic and recent tectonic processes in the surroundings of Dunaföldvár. Investigations of the relationships between the high bank movements and the water level of the River Danube, ground water table changes and the precipitation revealed that the tilt magnitudes caused by the ground water table variations are two orders of magnitude greater than the tilts caused by the water level regime of the river and the direct effect of the precipitation on the high bank tilts can be disregarded.
\end{abstract}

\section{Introduction}

The $30-80 \mathrm{~m}$ high loess banks along the west side of the River Danube in Hungary are greatly prone to landslides (Kleb and Schweitzer, 2001). The abrupt mass movements cause a lot of damage in settlements, industrial structures built on the high banks. Several landslides (e.g. in years 1960, 1970, 1973, 1994, 2004 and 2005) caused damage in the small town Dunaföldvár which is partly built on the high loess bank. This was the reason for the detailed hydrological, geological, and geomechanical investigations carried out earlier in the area (e.g. Horváth and Scheuer, 1976; Karácsonyi and Scheuer, 1972; Kleb and Schweitzer, 2001; Pécsi, 1971; Pécsi et al., 1979; Scheuer, 1979; Szabó, 2001) but relationships between movements of the high bank and geophysical, hydrometeorological, etc. processes were not studied at that time. In 2001 a test site has been established by the former Geodetic and
Geophysical Research Institute of the Hungarian Academy of Sciences (now Geodetic and Geophysical Institute, Research Centre for Astronomy and Earth Sciences, Hungarian Academy of Sciences (GGI RCAES of HAS)) to study the relationships between high bank movements and different natural factors. First a geodetic monitoring network was established, based on yearly repeated geodetic measurements (GPS, EDM, precise levelling) and continuous borehole tilt measurements (Mentes and Eperné, 2004). In 2005, a vertical borehole extensometer also was installed on the test site to monitor the vertical deformation of the high bank. Besides the deformation measurements, temperature, ground water table variations were monitored and water level fluctuations of the River Danube and precipitation data were involved into the investigations.

In contrast with the geodetic measurements the highly sensitive $\left(0.1 \mu \mathrm{rad}\right.$ corresponding to $0.0001 \mathrm{~mm} \mathrm{~m}^{-1}$ ) continuously recording borehole tiltmeters are well suited for observation of short pe-

\footnotetext{
* Corresponding author.

Email address: mentes@ggki.hu (G. Mentes)
} 
riodic and small ground tilts due to ground water level and pore pressure variations, as it was proved by pump tests (Fabian and Kümpel, 2003; Kümpel et al., 1996, 2001). Such kind of tiltmeters were used for landslide monitoring by e.g. García et al. (2010). Highly sensitive, continuously recording borehole tiltmeters and extensometers provide more information about the landslide movements than the intermittent measurement techniques (Uhlemann et al., 2016; Brückl et al., 2013; García et al., 2010; Corsini et al., 2005). They make possible to seek for quantitative connections between river bank movements and hydrological, meteorological processes (water level of the river, ground water table variations and precipitation events), which are in connection with the slow seepage material transport from the basal sediment to the river and the river erosion of the basal material. Many authors (e.g. Casagli et al., 1999; Chu-Agor et al., 2008; Fox et al., 2007; Guzzetti et al., 2008; Rahimi et al., 2010; Rinaldi et al., 2004) studied the effect of the precipitation, ground water and stream level variations onto river bank stability in connection with seepage caused slope failures and erosion. Wilson et al. (2007) carried out laboratory experiments on the basis of field measurements to study the impact of soil properties on seepage erosion and the resulting stream bank failure. Schnellmann et al. (2010) investigated experimentally the effect of rising water table in an unsaturated slope model. Angely et al. (1998) developed a combined hydrology/ stability model by means of which the cumulative landslide displacements could be estimated as a function of precipitation. The direct connection between hydrological processes and landslide movements have also been investigated by several authors (e.g. Bogaard and Greco, 2016; Lehmann et al., 2013; Springman et al., 2013).

Similarly to other effects, active tectonics can also play an important role in development of landslide processes as they are able to modify the slope geometry, causing structural discontinuities, and changing the gravity field (Alexander and Formichi, 1993; Rapolla et al., 2010). To detect the slow tectonic movements and their effects long-period and high accuracy deformation monitoring is necessary. This is why the relationship between landslides and tectonic movements has been mostly investigated using geomorphologic approaches (e.g. Agliardi et al., 2001; Dramis and Sorriso-
Valvo, 1994). Only some authors, e.g. Brückl et al. (2013) have carried out seismic measurements and continuous deformation measurements by geodetic methods and continuously recording extensometers.

In this paper the quantitative relationships between the movements of the high loess bank and the water regime of the River Danube, the ground water table, precipitation and temperature are investigated by two borehole tiltmeters and a vertical borehole extensometer. The possible effect of recent tectonics on the high bank movements is also studied on the basis of twelve-year long continuous data series recorded from 2002 to 2014.

\section{Study area}

Dunaföldvár is situated in the middle of Hungary on the right side of the River Danube, on the margin of the Mezofföld, which is characterized by NW-SE oriented valleys (Fig. 1). The bottom right corner of the Figure shows the locations and dates of the largest landslides in Dunaföldvár and the study area which is situated on the $120-130 \mathrm{~m}$ high a.s.l. (a.s.l. = above Baltic Sea level) Felső Öreghegy (Upper Old Hill). Fig. 2 shows the investigated section of the high bank and the traces of the landslide occurred in February 2005. In Fig. 3 the contour map of the study area is depicted. The loess plateau of the Felsó Öreghegy has a 20-30 m steep, nearly vertical hillside to the flood plain of the River Danube. The Felső Öreghegy is separated from the Alsó Öreghegy (Lower Old Hill) by a 150-200 m wide, N-S oriented, valley. Fig. 4 shows the simplified geological cross section of the area based on the results of geotechnical surveys carried out by Pyrus Ltd (1994). A detailed description of the geological setting of the high bank is given by Horvath and Scheuer (1976), Karácsonyi and Scheuer (1972) and Schweitzer et al. (1978).

The hydro-geological properties of the area are strongly influenced by the subsurface water flow from the elevated loess hinterland which is a water catchment area. The water supply is derived from the sand layers intercalated in the loess sequence, where the ground water is accumulated, and from the confined water stored in the first sandy Upper-Pannonian deposit (Fig. 4). The average

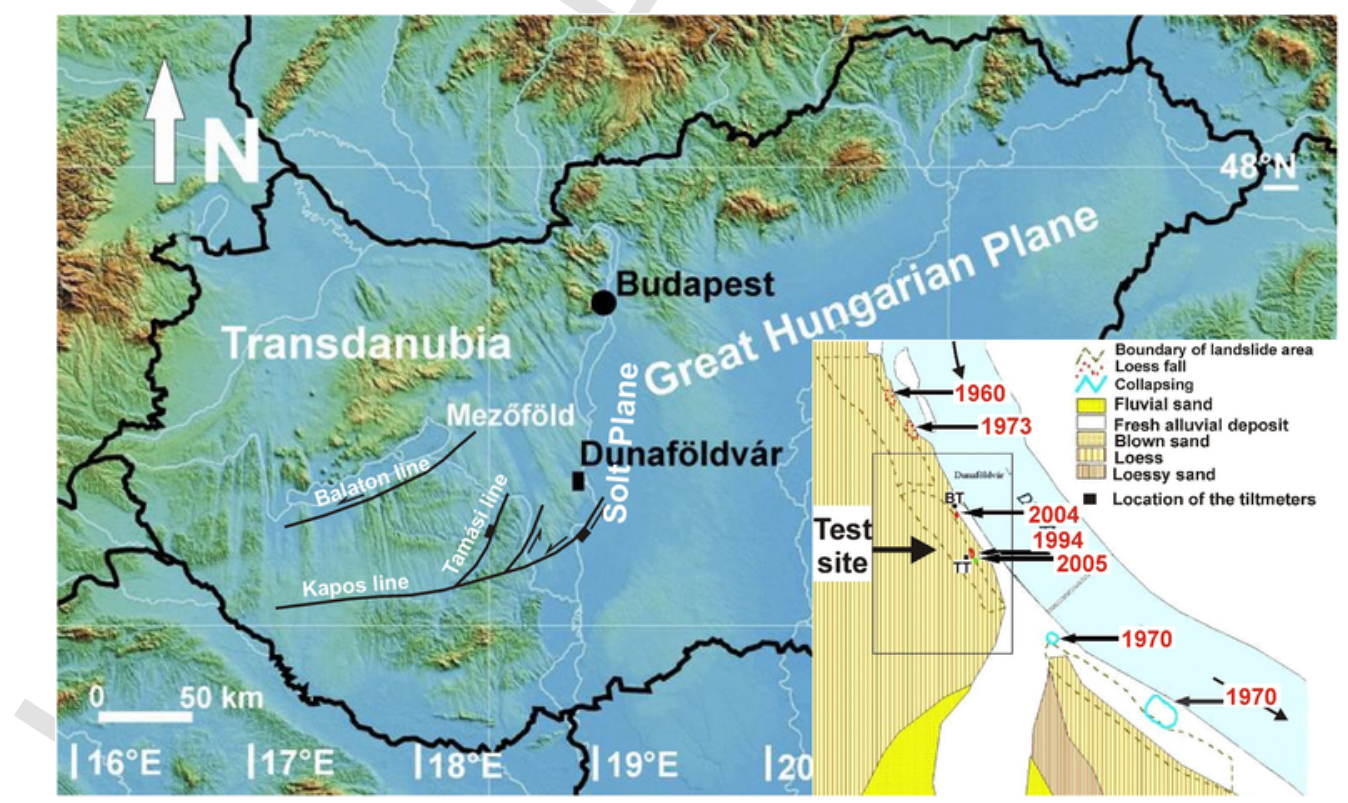

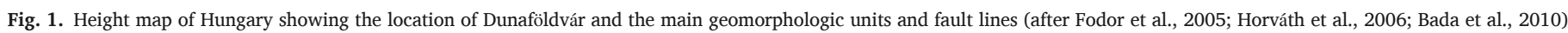
in the vicinity of the study area. In the bottom right corner the locations and years of the largest landslides on the test site and some geological features of the area are shown. 


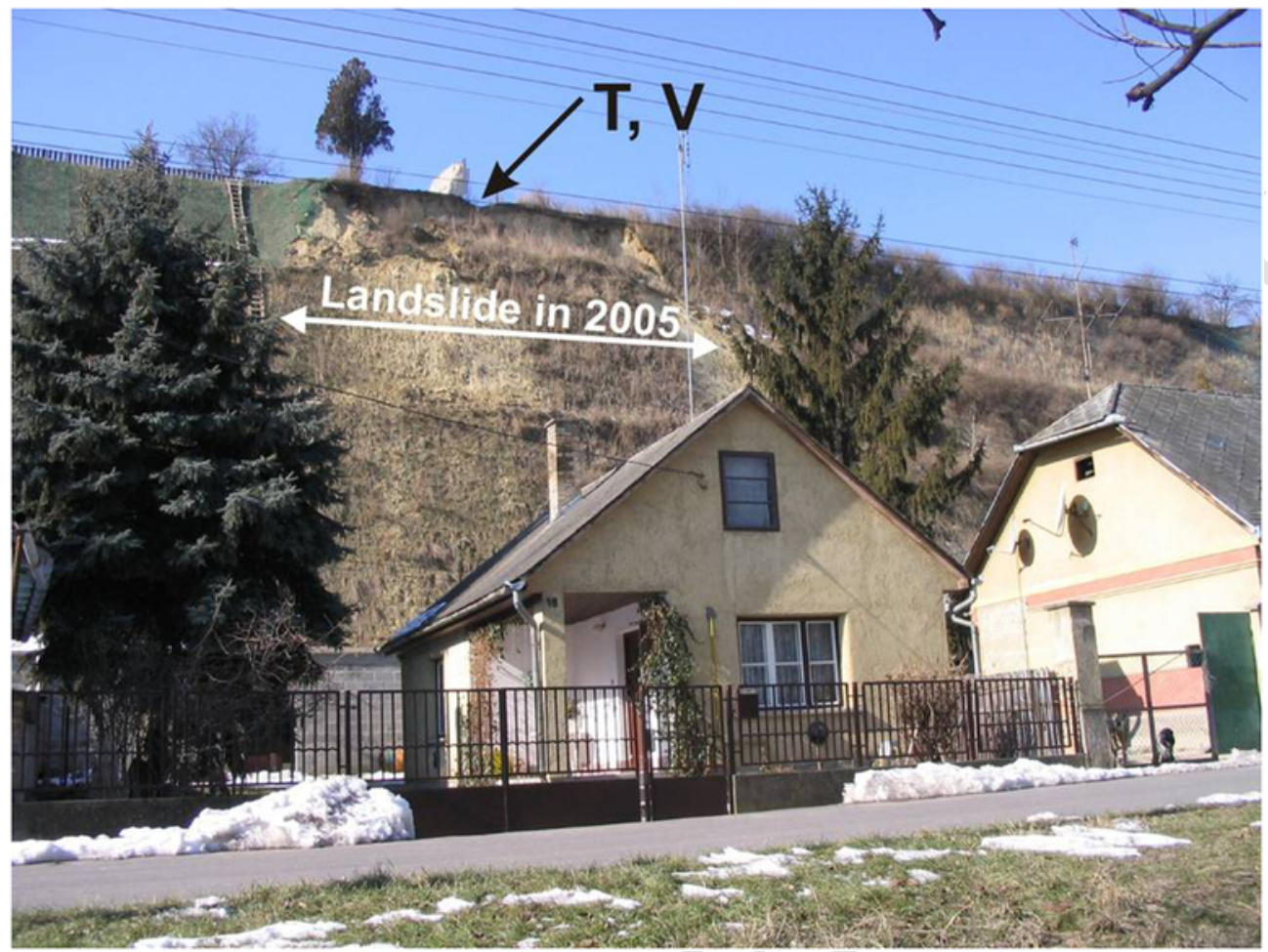

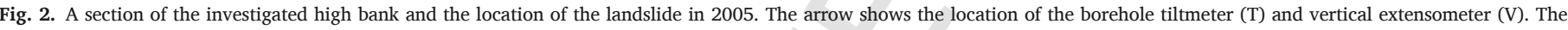
instruments are located about $8 \mathrm{~m}$ from the brink of the high bank.

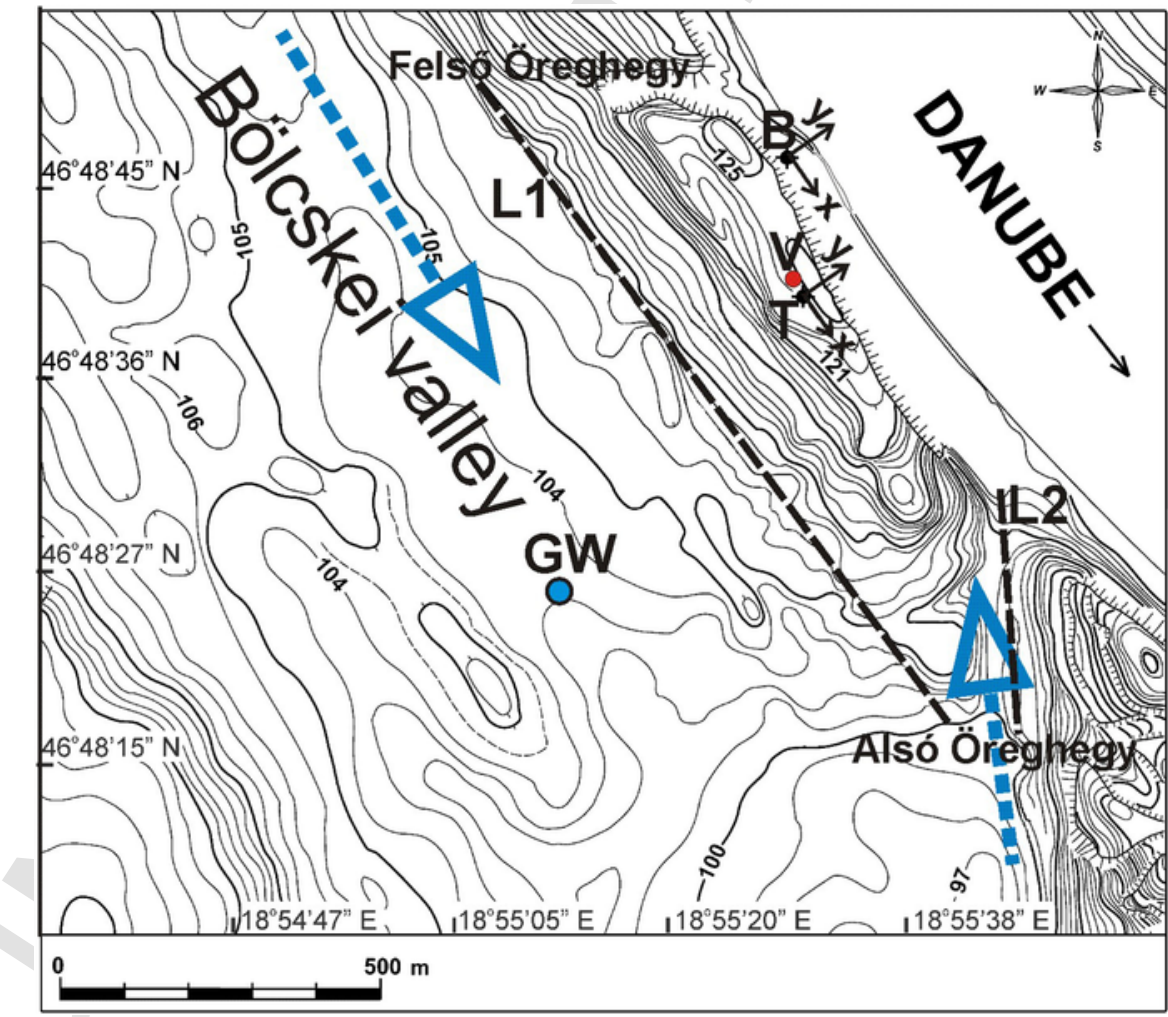

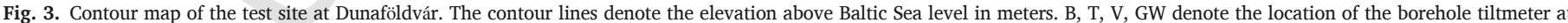

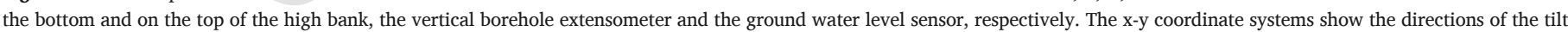

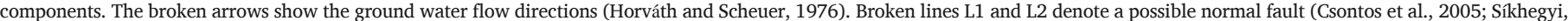
2002) and a dextral (right lateral) strike fault (Csontos et al., 2005), respectively. 


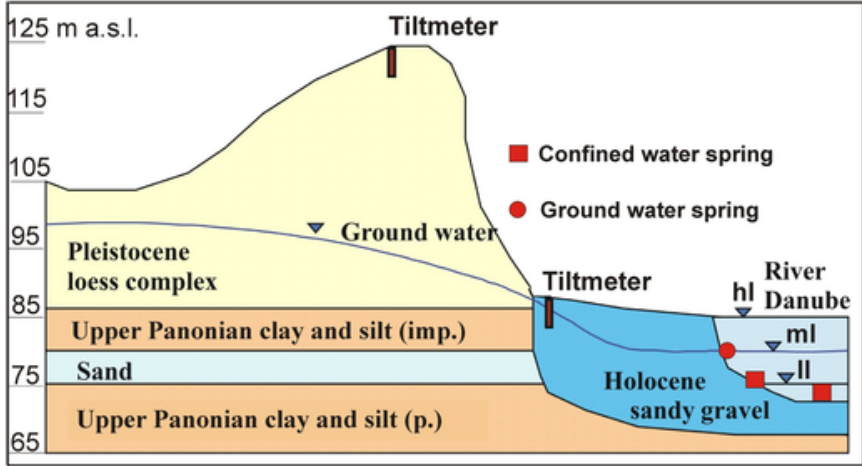

Fig. 4. Simplified geological and hydrological features of the study area (after Horvath and Scheuer, 1976; Karácsonyi and Scheuer, 1972). Legend: a.s.l: above (Baltic) sea level; hl: high water level; ml: mean water level; 11: low water level; (p.): permeable; (imp.): impermeable.

depth of the ground water table, depending on the characteristics of the terrain, is about $25-40 \mathrm{~m}$ in the loess-mantled area west of the margin of the high bank (Karácsonyi and Scheuer, 1972). The ground water flow direction is mainly eastward, but this is influenced by the valleys which reach the ground water table. In Fig. 3 the broken arrows show the direction of the ground water flow to the investigated high bank from the NW and SW (Horváth and Scheuer, 1976). At the margin of the high bank the ground water table falls steeply and the water is transferred to the sediments of the River Danube or breaks to the surface in form of springs or seepages $0.5-1 \mathrm{~m}$ above the mean water level of the river (Scheuer, 1979). The height of the ground water table is about 104-106 m a.s.l. in the sandy layer (Pleistocene loess complex) of the high bank and in the Holocene sandy gravel layer on the bank. Since the ground water has a hydrological connection with the River Danube, its level is largely influenced by the water level of the river (Horváth and Scheuer, 1976).

The study area is bordered on the NNW-SSE orientated Bölcskei valley from the west (Fig. 3). The 1-1.5 km wide Bölcskei valley is filled with silts of high organic content and it is a soggy area, 98-102 m a.s.l. The Pannonian basement rises gradually towards the west. On the east side of the town Dunaföldvár, the strip of the high bank is 64-87 $\mathrm{m}$ high a.s.l. On the west side of the Bölcskei-valley the height of the basement is already $102-112 \mathrm{~m}$ a.s.l. The Pannonian strata are not exposed in the strip of the high bank. The basement is $5-30 \mathrm{~m}$ deep under the mean water level of the River Danube (Schweitzer et al., 1978). Fig. 1 shows the characteristic NW-SE oriented, parallel arranged draining valleys and ridges west of the high bank in Transdanubia. It can be assumed that this orientation is due to the Alpine compression (Síkhegyi, 2002). The north-south oriented compression of the Eastern Alps is accompanied by vertical and lateral extrusion and tectonic escape of large crustal wedges towards the unconstrained margin in the east (Bada et al., 1999, 2001; Fodor et al., 2005; Horváth et al., 2006). The heterogeneous intensity of this extension is accommodated by transfer faults (some of them are shown in Fig. 1) bounding different regions (Csontos and Nagymarosy, 1998). Dunaföldvár lies in the SW-NE oriented mid-Hungarian shear zone. The internal deformation is characterized by late-stage subsidence anomalies and seismically active shear zones. In connection with the above mentioned SW-NE extension Síkhegyi (2002) and Csontos et al. (2005) identified a normal fault west of the test site, which is denoted with broken line L1 in Fig. 3. The ENE-WSW oriented L2 fault between Felsô and Alsó Öreghegy can be supposed to be a shortening induced dextral (right lateral) strike fault (Csontos et al., 2005). The geological and geomorphologic properties of the vicinity of the area are described by Mentes et al. (2009) in detail.

\section{Methods}

In the middle of 2002 two borehole tiltmeters, Model 722A made by Applied Geomechanics Inc. (2016) were installed to monitor high bank tilts. These tiltmeters have a dual-axis tilt and a built-in temperature sensor. This latter served for instrument and soil temperature measurement in the borehole. The resolution of the tilt and temperature sensors is $0.1 \mu \mathrm{rad}$ and $0.1{ }^{\circ} \mathrm{C}$, respectively. The tiltmeters were installed in $3 \mathrm{~m}$ deep boreholes which ensured a stable operating temperature for the instruments. According to our investigations the drift of the tiltmeters is negligible (Mentes and Bódis, 2012; Mentes, 2003; Mentes et al., 1996). The installation of the tiltmeters is shown in Fig. 5a. One tiltmeter was located on the top (T) and the other at the bottom (B) of the high bank (Figs. 3 and 4). This latter tiltmeter is about $50 \mathrm{~m}$ from the River Danube and is below the ground water level, but this circumstance does not influence its measurement capacities (Mentes, 2004). The $+y$ tilt axes of the tiltmeters are directed perpendicular to the River Danube pointing approximately towards the east, and so the $+x$ tilt axes are parallel to the river pointing approximately towards the south. Due to the bend of the river in the study area the coordinate system of the tiltmeters is counter-clockwise rotated to the north by about $30^{\circ}$ (see Fig. 3) which is taken into consideration at the determination of the tilt direction of the high bank.

In 2005 a sensitive borehole wire extensometer (V) was installed close to the tiltmeter $\mathrm{T}$ (Fig. 3) to measure vertical ground movements in the upper layer of the high bank due to meteorological and hydrological processes. The extensometer is $3 \mathrm{~m}$ long and it is able to measure distance variations in a range of $0-4 \mathrm{~mm}$ with a resolution of $1 \mu \mathrm{m}$. The instrument is temperature compensated. The construction and installation of the extensometer is shown in Fig. 5b. The description of the instrument is given by Mentes (2012) in detail.

The ground water level has been measured by a sensor produced by Dataqua (2016) since 2011. The location of the well where the ground water level was recorded is denoted by GW in Fig. 3.

The tilt, extensometric, temperature and ground water level data were recorded hourly. The precipitation was not directly measured at the test site. We used data which were measured in Dunaföldvár and were supplied by the Hungarian Meteorological Service. Daily averages water level data (DWL) of the River Danube have been downloaded from the publicly available website of the Directorate of Water Management (2016).

Since we had daily precipitation and water level data of the River Danube we also calculated the daily averages of tilt, extensometric, temperature and ground water level data from the hourly measured values. To investigate the relationships between tilt, extensometric data and water level, temperature data, the daily averaged data series were subjected to Multivariable Regression (MVR) analysis. A polynomial of ninth order was fitted to the tilt data series (low-pass filtering) to study the long-term tilts of the high bank and their possible connection with recent tectonics. Data processing was carried out by the ORIGIN 9.1 (2014) program.

\section{Results and discussion}

\subsection{Long-term tilt}

Fig. 6 shows the daily averaged tilt data measured at the toe (BN, $\mathrm{BE}$ ) and on the top (TN, TE) of the high bank and the soil tem- 


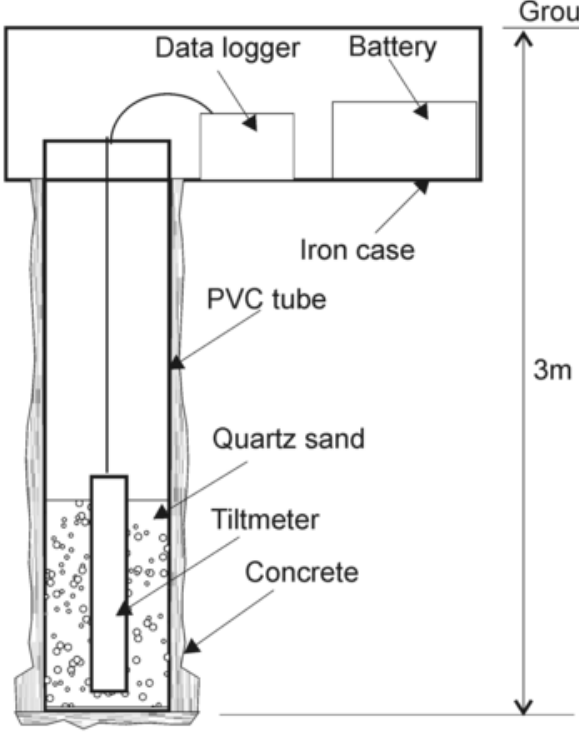

a)

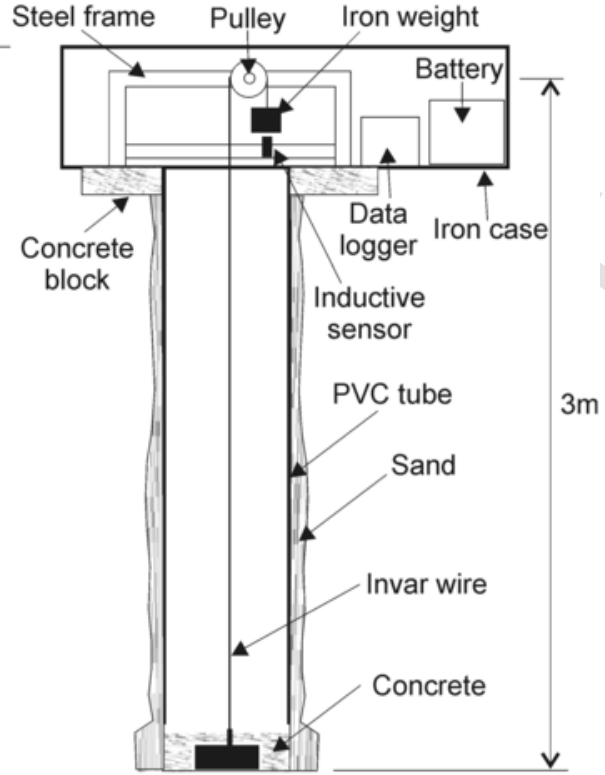

b)

Fig. 5. Installation of the tiltmeters (a) and the vertical extensometer (b) in the boreholes.

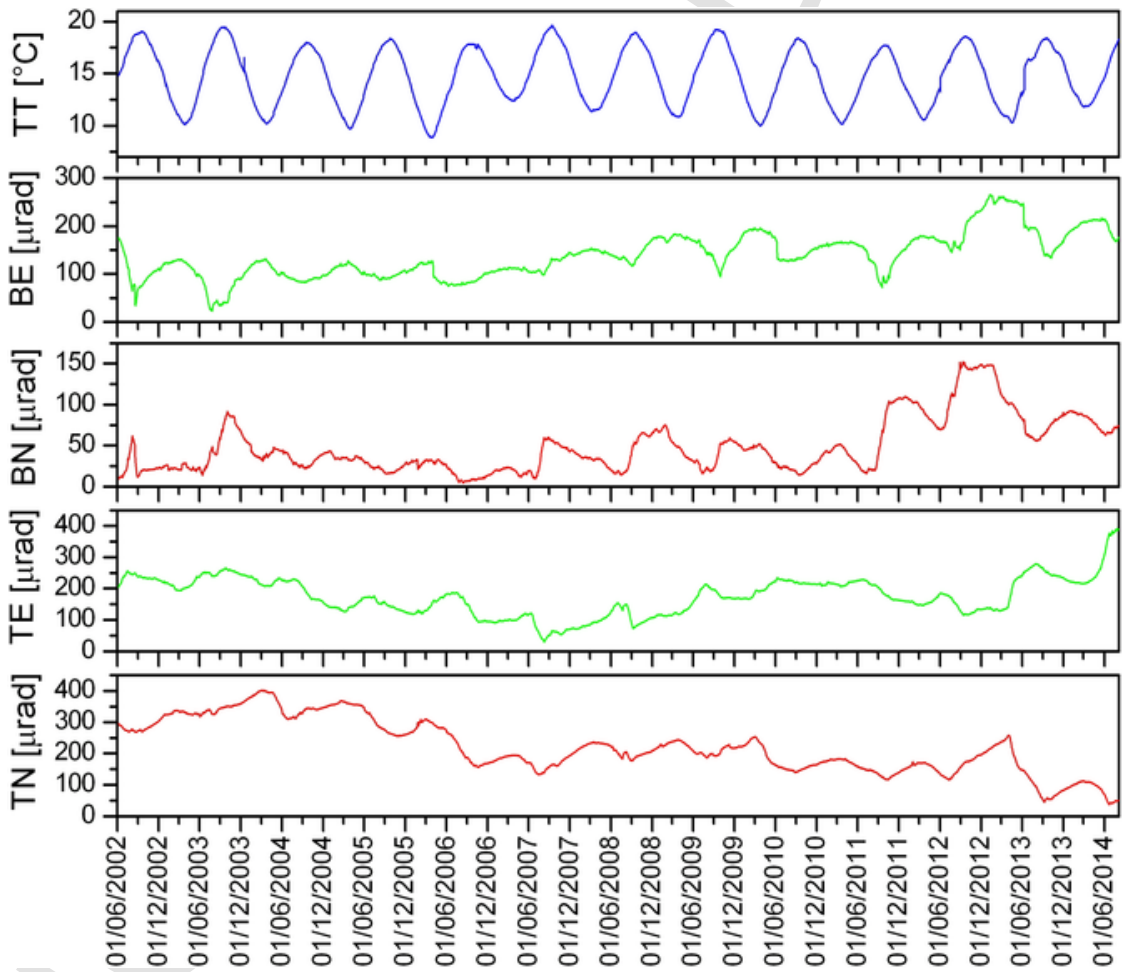

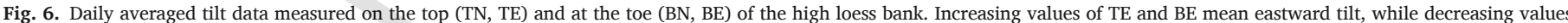

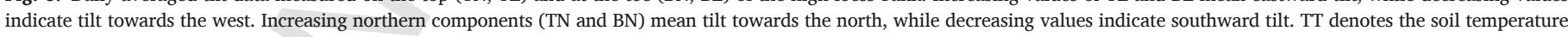
measured on the top of the high bank.

perature (TT) measured on the top of the high bank from 01.06.2002 to 31.07.2014. Increasing values of $\mathrm{TE}$ and $\mathrm{BE}$ mean eastward tilt, while decreasing values indicate tilt towards the west. Increasing northern components (TN and $\mathrm{BN}$ ) mean tilt towards the north, while decreasing values indicate southward tilt. The linear trend of the tilt data was estimated by fitting a regression line to the tilt curves. The steepness of this line gives the rate of the long-term tilt. The obtained tilt rates in the east and south directions in $\mu \mathrm{rad} / \mathrm{year}$, the standard deviations of the tilt rate determinations, the correlation coefficients and the resultant tilt rates calculated from the east and south tilt rate components are given in Table 1 . The direction of the resultant tilt rates are given in the north-east coordinate system. The top of the high bank tilts in the SSE, while the bottom of the high bank tilts in the NEE direction.

The long-term tilt data are influenced by short periodic local effects as the Danube's water level and ground water table varia- 
Table 1

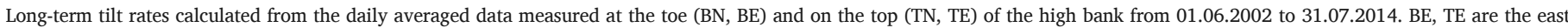
and $\mathrm{BN}, \mathrm{TN}$ are the north tilt components, respectively.

\begin{tabular}{|c|c|c|c|c|c|}
\hline Tilt components & $\begin{array}{l}\text { Tilt rate } \\
{\left[\mu \mathrm{rad} \mathrm{y}^{-1}\right]}\end{array}$ & $\begin{array}{l}\text { Standard } \\
\text { deviation } \\
{\left[\mu \mathrm{rad} \mathrm{y}^{-1}\right]}\end{array}$ & Correlation coefficients & Resultant tilt rate (direction) & Resultant tilt in 12 years (direction) \\
\hline $\mathrm{TE}$ & 1.52 & 0.25 & 0.089 & $20.43 \mu \mathrm{rad} \mathrm{y}^{-1}$ & $248 \mu \mathrm{rad}$ \\
\hline $\mathrm{TN}$ & -20.38 & 0.19 & 0.846 & (SSE) & (SSE) \\
\hline $\mathrm{BE}$ & 10.04 & 0.13 & 0.766 & $11.51 \mu \mathrm{rad} \mathrm{y}^{-1}$ & $141 \mu \mathrm{rad}$ \\
\hline $\mathrm{BN}$ & 5.64 & 0.11 & -0.604 & (NEE) & (NEE) \\
\hline
\end{tabular}

tions, precipitation, temperature, etc. To show the long-period movements of the high bank, the short-period variations of the tilts were eliminated by fitting a polynomial of ninth order to the raw tilt data series (Fig. 7). In Fig. 8 the north components are plotted vs. east components of the tilt data polynomials to show the movements of the top and the bottom of the high bank separately. Fig. 9

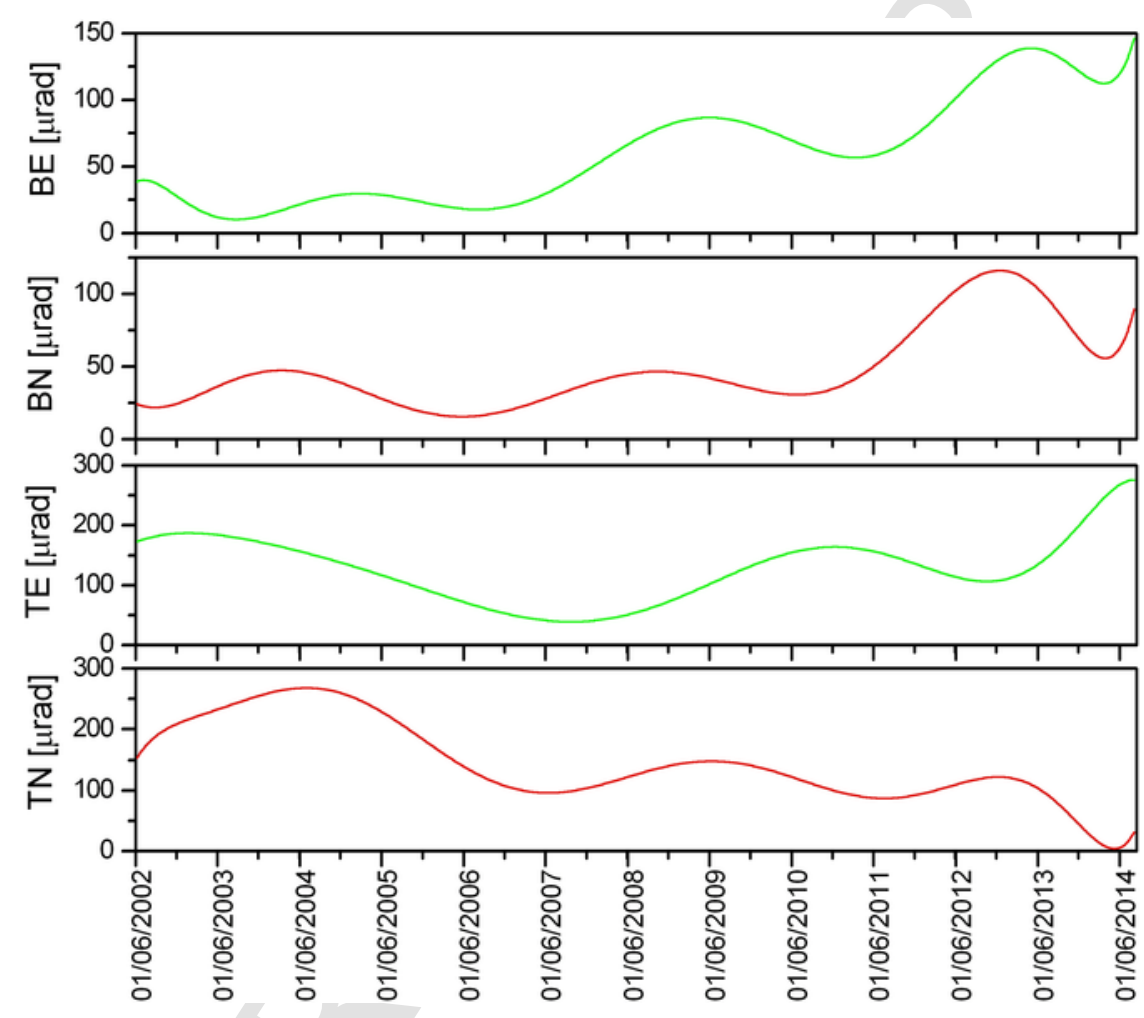

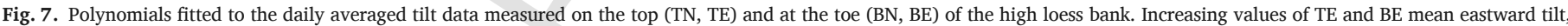
while decreasing values indicate tilt towards the west. Increasing northern components (TN and BN) mean tilt towards the north, while decreasing values indicate southward tilt.

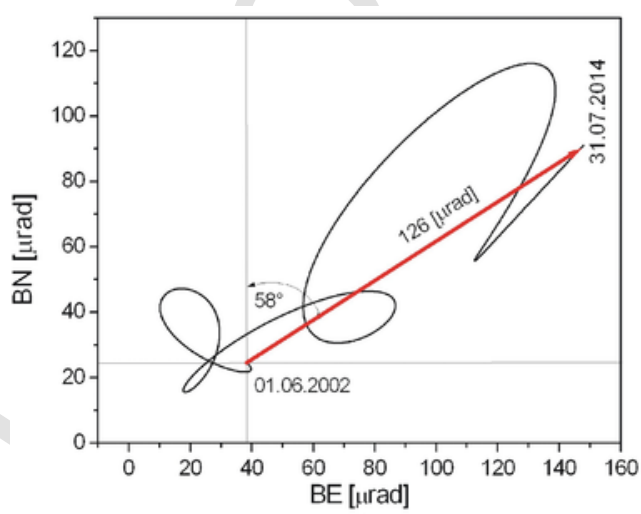

a)

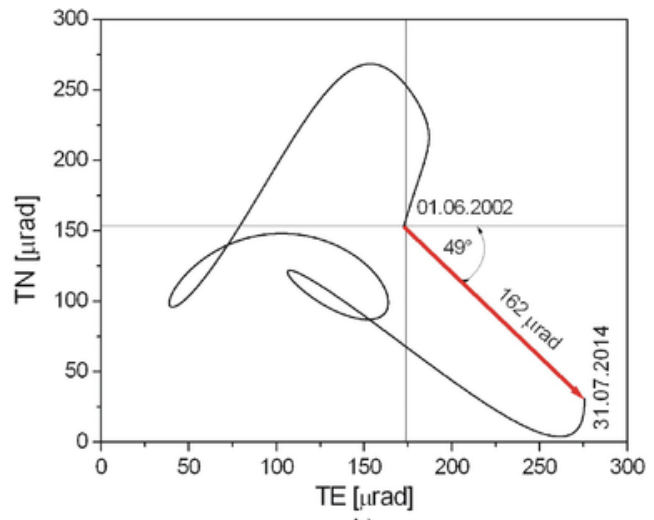

b)

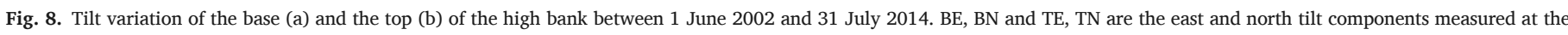
toe and on the top of the high bank, respectively. The thick arrows show the total tilts during the observation. 


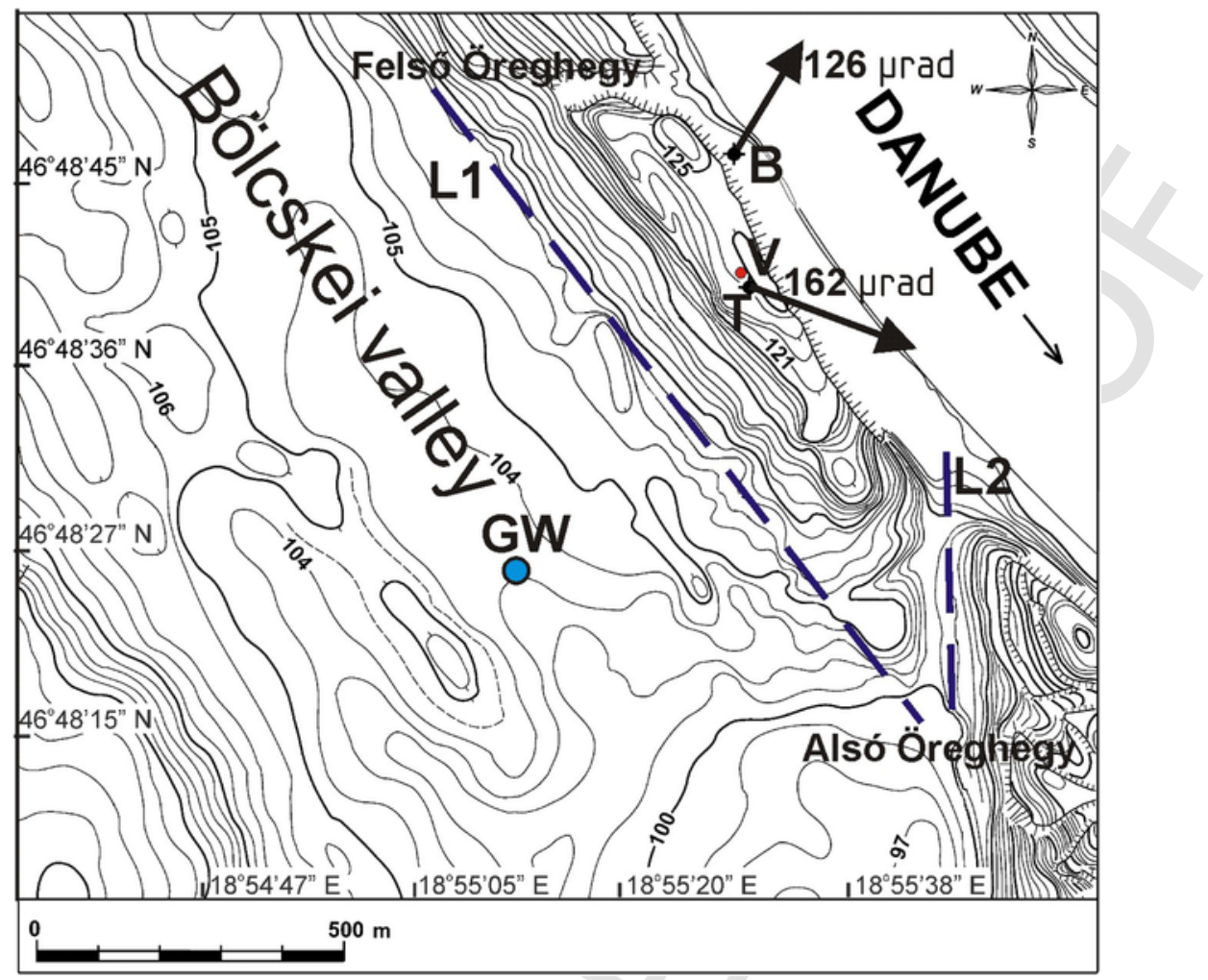

Fig. 9. Total tilt of the high bank between 1 June 2002 and 31 July 2014.

shows the magnitude and the direction of the total tilt of the top and toe of the high bank in the observation interval, from 1 June 2002 to 31 July 2014. The tilts directions are about the same which were obtained from the raw data by linear regression, but the tilt magnitudes calculated from the tilt rates (see Table 1) are greater than the tilts measured from 1 June 2002 to 31 July 2014. This is due to the different methods of the resultant tilt determination.

The long-term tilt of the high bank can be interpreted in three different ways: it is due to either geomorphologic processes or recent tectonic movements or a combination of both processes. The third seems to be the most likely explanation. In the first case the River Danube undercuts the high bank and washes away its material. The flow of the groundwater contributes to this process which causes the eastward tilt of the high bank and its base (see in Section 4.3). The northward tilt of the base slope of the high bank can be explained by the water flow direction of the river. The northern part of the high bank base has more mass loss than the southern part since the water flows from the north to the south. This process occurs due to the development of the river bend (Lóczy and Gupta, 2007). These processes explain the tilt of the high bank base in the NEE and the tilt of the high bank in the east but do not shed light on the southward tilt component of SSE tilt direction of the high bank. This component can be explained by the ground water flow in the valley southward from the investigated high bank section (see Fig. 3) causing an increased discharge of the base material and so a southward tilt of the high bank. The second hypothesis can be supported by the assumption that the faults on the test site are active. The territory west of the test site is in a compressional, push-up neotectonic regime triggering morphological uplift west of Dunaföldvár (Horváth et al., 2006; Csontos et al., 2005). According to Síkhegyi (2002) the L1 fault (Fig. 3) is a normal fault contributing to the eastward tilt of the high bank. The southern part of the investigated high bank section along the L2 fault is pushed downstairs causing the southern component of the tilt. This is caused by the S-N compression of the Pannonian Basin due to the push and counter-clockwise rotation of the Adriatic plate (Csontos et al., 2005; Horváth et al., 2006; Síkhegyi, 2002). The subsidence of the Solt Plain (e.g. Ruszkiczay-Rüdiger et al., 2005) on the opposite bank of the River Danube (see Fig. 1) can also contribute to the eastward tilt of the high bank (Síkhegyi, 2002).

\subsection{Effect of precipitation}

Fig. 10 shows the daily averaged tilt and precipitation data series recorded between 6 June 2002 and 31 December 2007. No significant direct connection can be detected between the tilt components and precipitation, not even in the case of high precipitation events $(60-80 \mathrm{~mm})$. As an example Fig. 11 shows the cumulative precipitation (CP), vertical extensometric (VE) data and the north (TN) and east (TE) tilt components of the high bank between 1 and 30 May 2006. It is obvious that the precipitation causes only very small tilts and vertical movements increasing the pore pressure in the upper layer in the loess, which proves that the rainwater, especially during heavy rains runs off from the high bank or flows into the cracks in the loess decreasing its strength in the lower layers. The tilt directions are not always the same due to the rainfalls which means that other effects are also present (Mentes and Bódis, 2012). Correlation and linear regression analyses were performed between the cumulative precipitation and the tilt and extensometric values. Before the analysis a linear trend was subtracted from the tilt and extensometric values to eliminate the false correlation between the stepwise increasing cumulative precipitation and the long-term tilt and vertical extension. Results are shown in Table 2 . It can be seen that $1 \mathrm{~mm}$ precipitation causes about $0.04 \mu \mathrm{m}$ vertical extension and less than $0.02 \mu \mathrm{rad}$ tilts. The time lags between the cumulative precipitation and the extensometric and tilt values were also investigated by correlation analysis. Fig. 


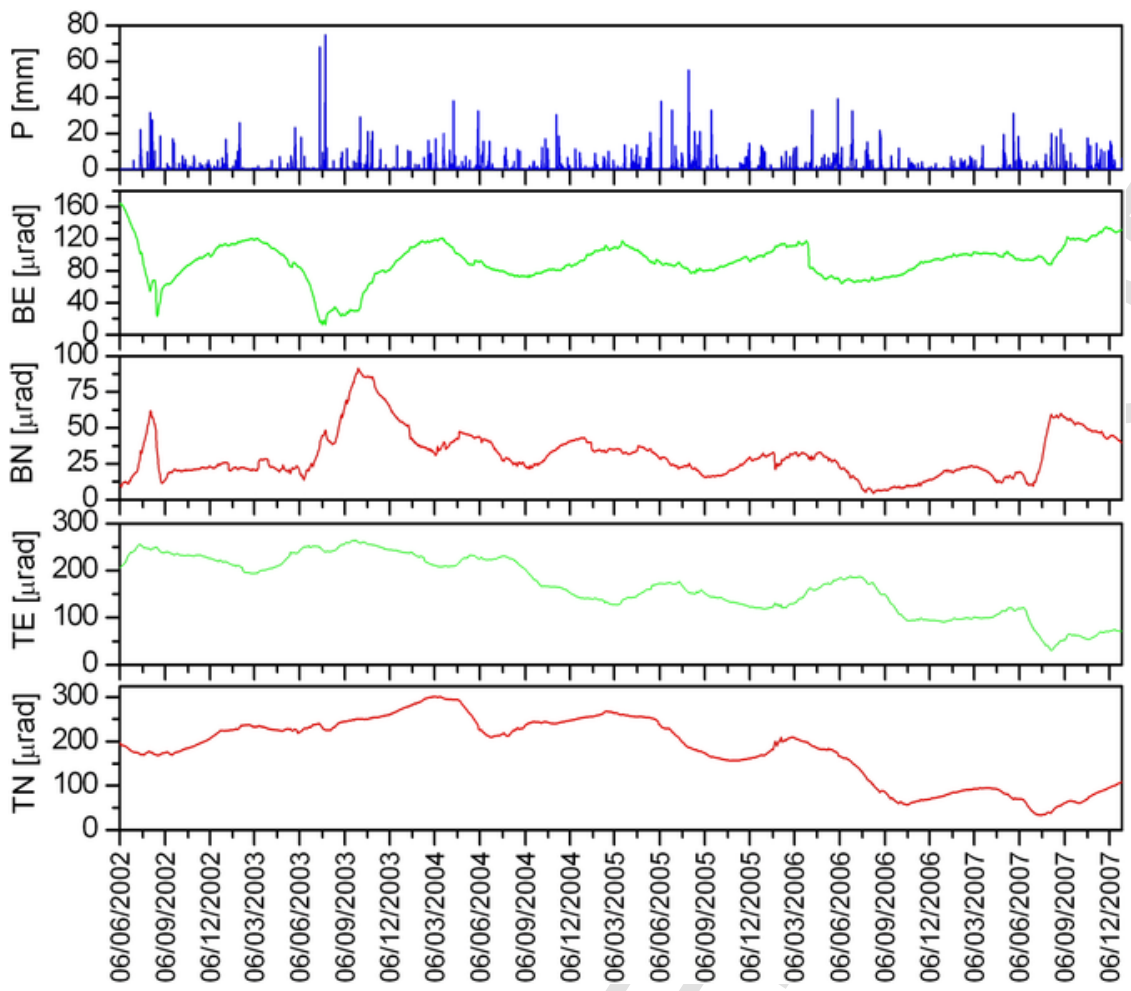

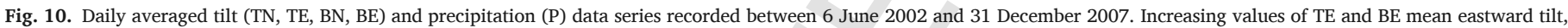
while decreasing values indicate tilt towards the west. Increasing northern components (TN and BN) mean tilt towards the north, while decreasing values indicate southward tilt.

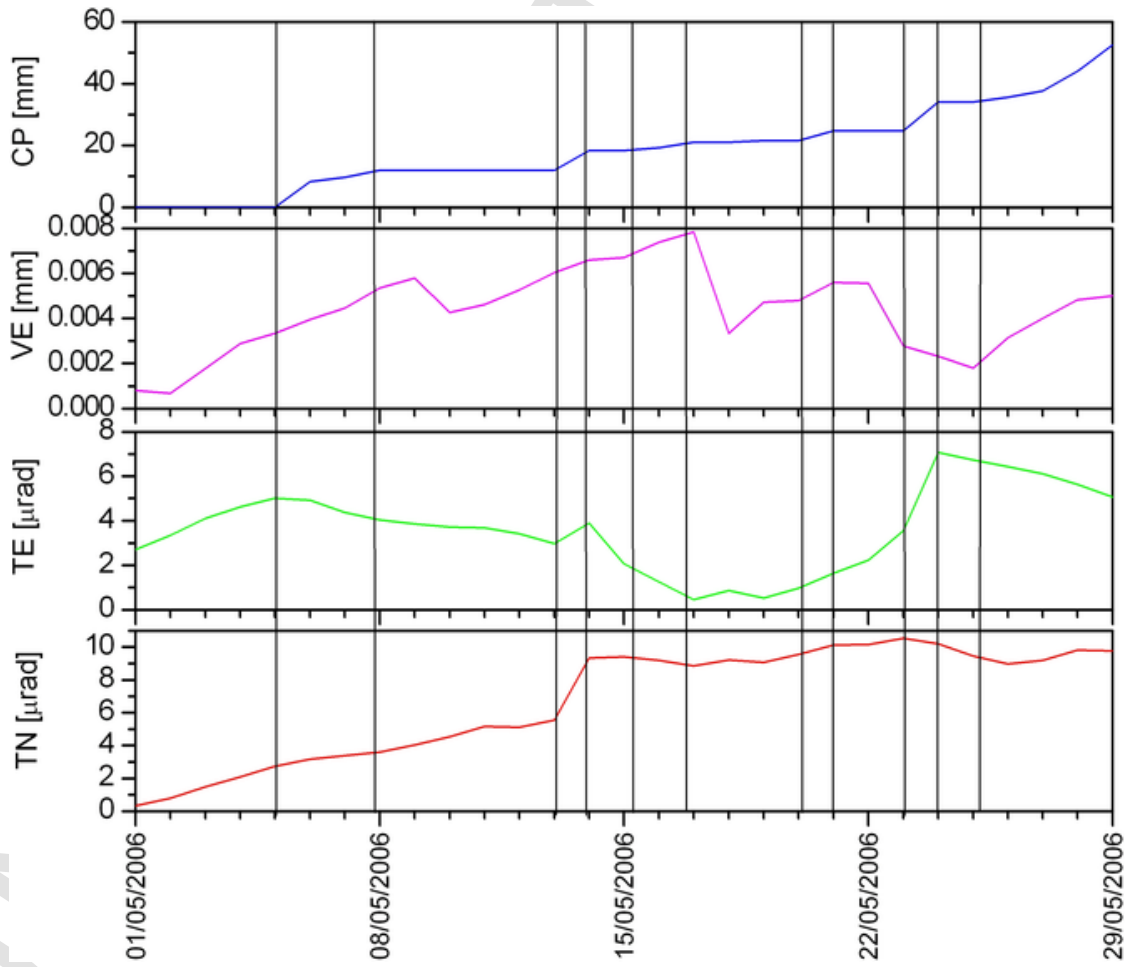

Fig. 11. Daily averaged vertical extensometer (VE) and cumulative precipitation (Cum. precip.) data series recorded between 1 and 30 May 2006.

12 shows the results. The maximum correlation between the precipitation and the vertical extension occurs about two days after the rainfall. After 2 days the correlation coefficient decreases continuously. In the case of the tilt components the time delay is about 4-6 days (see the $\mathrm{BN}$ tilt component) and with exception of $\mathrm{BN}$ the absolute values of the correlation coefficients are increasing (TN, BE) or decreasing (TE) continuously. In these cases an accurate determination of the time lag is not possible, probably due to the superposed strong influence of the ground water table and river 
Table 2

Results of the regression and correlation analysis between vertical extension (VE), tilt data and cumulative precipitation (CP). TN, TE and BN, BE are the north and east tilt components of the top and bottom of the high bank, respectively.

\begin{tabular}{lll}
\hline Data & CP & \\
\hline & Corr. coeff. & Reg. coeff. \\
\hline VE & 0.785 & $0.040 \mu \mathrm{mm}^{-1}$ \\
TN & -0.123 & $-0.009 \mu \mathrm{rad} \mathrm{mm}^{-1}$ \\
TE & 0.566 & $0.026 \mu \mathrm{rad} \mathrm{mm}^{-1}$ \\
BN & 0.125 & $0.003 \mu \mathrm{rad} \mathrm{mm}^{-1}$ \\
BE & -0.484 & $-0.022 \mu \mathrm{rad} \mathrm{mm}^{-1}$
\end{tabular}

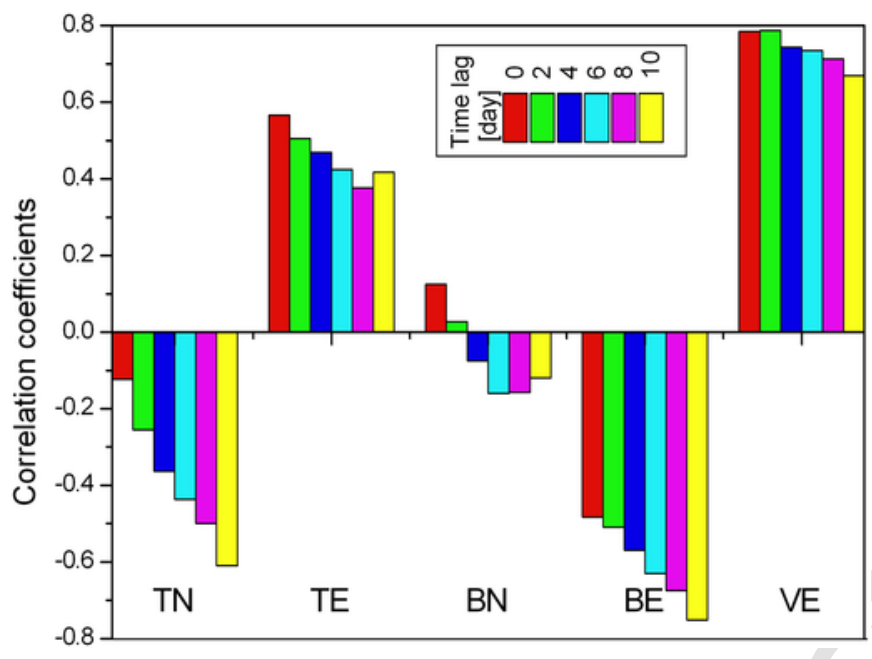

Fig. 12. Change of the correlation coefficients between vertical extensometer (VE), tilt components (TN and TE are the north and east tilt components of the high bank, respectively) and the cumulative precipitation (CP) data series due to change of the time lag between precipitation and the extensometric and tilt data. Negative correlation coefficients mean westward and southward tilt and vertical compression due to increasing cumulative precipitation.

stage fluctuations. We can assume that the time lag of the effect of the rainfall is between 2 and 8 days. Other authors relate similar values, e.g. Lollino et al. (2006) obtained a time lag of 9 days at the Montaldo di Cosola test site in Italy. The large lags show that the regional precipitation should have a much larger effect than the local rainfall. It is probably owing to the fact that the vertical permeability of loess is $2-3$ order of magnitude lower than the permeability of the horizontal sand layers (see Fig. 4) in the high bank (Karácsonyi and Scheuer, 1972), so the water infiltration from above is much lower than the ground water afflux from the hinterland, and thus the ground water level variations cause much larger tilts than the rainfall in the study area. Guzzetti et al. (2008) investigated the effect of intensity and duration of rainfall on the stability of shallow hill-slopes and found that rainfalls exciding about $48 \mathrm{~h}$ can initiate slope failures. He showed that the threshold for arising slope failures depends on climate and the antecedent rainfalls and soil moisture. According to Mentes and Bódis (2012), the effect of precipitation is also strongly influenced by the vegetation on the high bank. On the basis of our investigation we can state that the direct effect of the precipitation on the movements of the high bank can be disregarded and the precipitation mainly changes the stability of the high bank by decreasing the shear strength of loess and the friction along the slip planes (see also Li et al., 2015).

\subsection{Effect of the ground water table, the river water level variations and the temperature}

Fig. 13 shows the tilt (TN, TE, BN, BE), the vertical extension (VE), the ground water table (GW) and the Danube's water level variation (DWL) data series recorded from 3 March 2011 till 31 August 2014. As it can be seen in Fig. 6 the tilt data have a seasonal variation which is in connection with the ground temperature. This is the motion of the high bank due to the thermal effect and it is not of instrumental origin (Mentes, 2012; Mentes and Bódis, 2012; Mentes, 2003). The effect of the temperature on the high bank tilts was investigated by Mentes and Bódis (2012) in detail. For this reason the ground temperature data series is not plotted in Fig. 13 but it is involved into the data analysis. Some correlations between the data series are obvious in Fig. 13. The increasing ground water level causes decreasing vertical extension and conversely. It can be explained as follows: the increasing pore pressure in the lower part of the high bank due to the increased ground water level causes vertical compression acting against the gravity force of the upper layer. Therefore, the extensometer measures shortening in the upper layer of the high bank. The connection between the ground water level and the north components (TN and $\mathrm{BN}$ ) of the tilts is also conspicuous. To obtain a numerical connection between each tilt component and the water level variation of the River Danube (DWL), the ground water level (GW) variation and the temperature $(\mathrm{T})$ the data series were subjected to MVR and correlation analysis. The analysis was carried out with yearly data to study the yearly changes of the obtained regression and correlation coefficients which characterize also the stability of the high bank. We can assume that lower coefficients mean higher high bank stability, since e.g. a unit of ground water level change causes smaller tilt than in the case when the high bank is in an unstable state. The MVR and correlation analyses were carried out with extensometric data similarly to the tilt data. The results (regression coefficients \pm RMS errors of their determination, $\mathrm{R}^{2}$ is the quality of the determination of the regression coefficients and correlation coefficients) are summarized in Tables 3 and 4. It can be seen that the effect of the ground water table variations are about two orders of magnitude higher than that of the water level range of the River Danube. There are no significant changes in the values of the yearly regression coefficients which mean that the highbank is in the same stability state. This is proved by the fact that in the investigated period (2011-2014) there were no landslide events in the study area.

\section{Conclusions}

The twelve-year long observation of the movements of the high loess bank by borehole tiltmeters and extensometer have made it possible to study the high bank movements due to slow recent tectonic and geomorphologic processes and the short-period (from hours to months) movements caused by hydrometeorological effects. The results revealed that besides geomorphologic processes recent tectonics can also play an important role in the recurrent landslides in the area. The measured long-period tilt direction of the high bank is in good agreement with recent tectonic processes. As a result of the superposition of the tectonic and geomorphologic effects, landslides can be triggered in 10-15 year intervals (recently, in 1994 and 2005) concentrated on the southern end of the investigated high bank section.

The magnitude of the high bank tilt due to the ground water table variations is about $10-100 \mu \mathrm{rad} \mathrm{m}^{-1}$, while a change of $1 \mathrm{~m}$ 


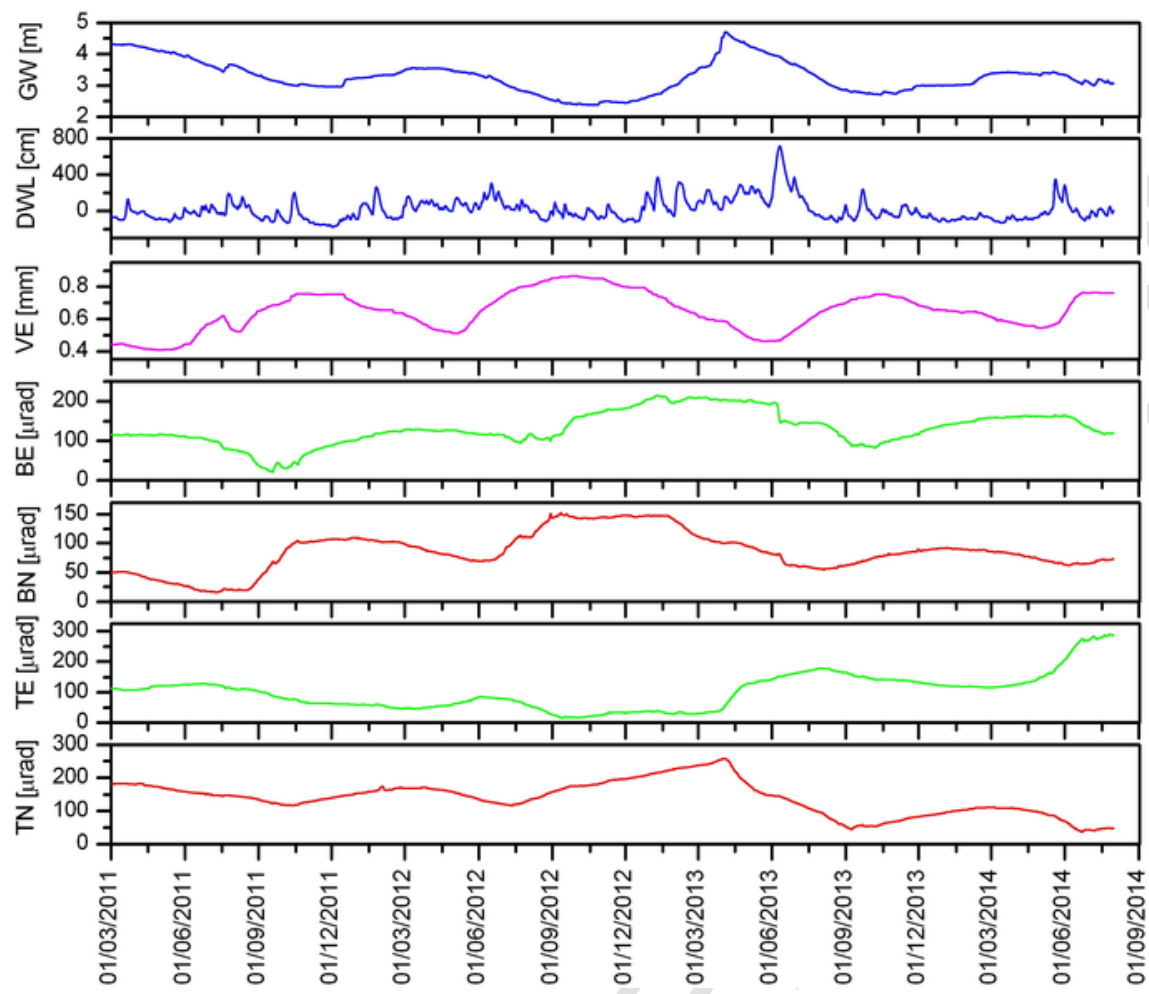

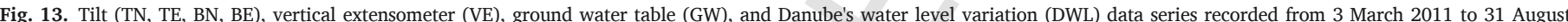

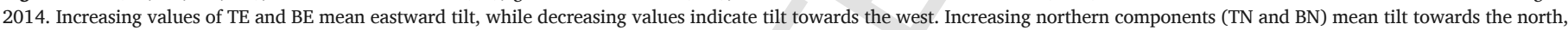
while decreasing values indicate southward tilt.

in the river level causes a 1-5 $\mu$ rad tilt of the high bank. The direction of the resultant tilt due to ground water table and river level variations is $E$-SE in most cases. Since the effect of the ground water level depends also on the river regime, the magnitude of the resultant tilt due the interaction of these two processes can be higher than 20-30 $\mu$ rad. During the whole recording period, the highest tilt variations were about $300 \mu \mathrm{rad}$ on the top and $200 \mu \mathrm{rad}$ at the bottom of the high bank.

The direct effect of the precipitation on the high bank tilts is negligible. However, it influences the high bank stability through changing soil properties.

Continuous tilt measurements showed that the effect of hydrological processes is more complicated than it had been claimed from geomechanical and hydrogeological investigations.

For a more exact interpretation of motions and deformations of the high bank due to hydrological processes, further research is needed on local hydraulic conditions:

- ground water levels should be measured at the southern and northern ends and in the middle directly at the back of the high bank,

- altogether four tiltmeters should be installed on the test site: at both ends on the top and at the toe of the high bank,
- pore pressure should be measured at different places and different depths on the high bank,

- distribution of the precipitation in the catchment area of the test site should be continuously determined.

The investigations showed that high-sensitive borehole tiltmeters are very useful and indispensable instruments for understanding kinematic and dynamic landslide processes. Due to their high spatial and temporal resolution, high stability and plainness for maintenance they are very suitable for long-term monitoring of landslides as a part of an early warning system.

\section{Acknowledgements}

The author thanks Professor Markus Stoffel for the careful handling of the manuscript and the two anonymous reviewers for their valuable comments and suggestions which helped to improve the paper. This research was supported by the Hungarian Scientific Research Fund under the project OTKA K 81295. The author is very grateful for the technical assistance from the local government and the Water Works of Dunaföldvár as well as to Tibor Molnár for the careful maintenance of the instruments. 
Table 3

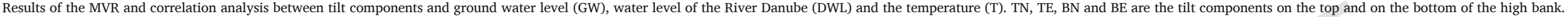

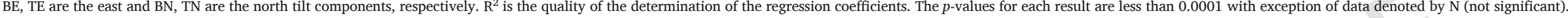

\begin{tabular}{|c|c|c|c|c|c|c|c|c|}
\hline \multirow[t]{2}{*}{ Years } & \multirow[t]{2}{*}{ Tilt components } & \multicolumn{2}{|l|}{ GW } & \multicolumn{2}{|l|}{ DWL } & \multicolumn{2}{|l|}{$\mathrm{T}$} & \multirow[t]{2}{*}{$\mathrm{R}^{2}$} \\
\hline & & Corr. coeff. & 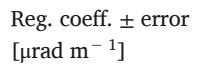 & Corr. coeff. & 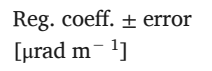 & Corr. coeff. & $\begin{array}{l}\text { Reg. coeff. } \pm \text { error } \\
{\left[\mu \mathrm{rad}{ }^{\circ} \mathrm{C}^{-1}\right]}\end{array}$ & \\
\hline \multirow[t]{4}{*}{2011} & $\mathrm{TN}$ & 0.925 & $11.856 \pm 1.011$ & 0.076 & $0.831 \pm 0.309$ & -0.973 & $-5.740 \pm 0.185$ & 0.971 \\
\hline & $\mathrm{TE}$ & 0.785 & $81.410 \pm 2.895$ & 0.445 & $-0.053 \pm 0.009$ & -0.451 & $9.143 \pm 0.531$ & 0.838 \\
\hline & BN & -0.673 & $-76.898 \pm 1.545$ & -0.507 & $0.381 \pm 0.868 \mathrm{~N}$ & -0.249 & $-10.995 \pm 0.303$ & 0.920 \\
\hline & $\mathrm{BE}$ & 0.729 & $29.307 \pm 2.629$ & 0.010 & $1.267 \pm 1.476 \mathrm{~N}$ & -0.709 & $-5.626 \pm 0.516$ & 0.684 \\
\hline \multirow[t]{4}{*}{2012} & $\mathrm{TN}$ & -0.392 & $-122.526 \pm 2.282$ & -0.307 & $0.526 \pm 0.525$ & -0.031 & $-18.045 \pm 0.349$ & 0.898 \\
\hline & $\mathrm{TE}$ & 0.704 & $65.010 \pm 3.670$ & 0.572 & $3.655 \pm 0.812$ & -0.468 & $6.544 \pm 0.547$ & 0.682 \\
\hline & BN & -0.906 & $-74.539 \pm 1.274$ & -0.576 & $-1.796 \pm 0.497$ & 0.308 & $-4.487 \pm 0.180$ & 0.941 \\
\hline & $\mathrm{BE}$ & -0.559 & $-77.489 \pm 2.854$ & -0.314 & $5.589 \pm 1.114$ & -0.122 & $-9.019 \pm 0.403$ & 0.709 \\
\hline \multirow[t]{4}{*}{2013} & $\mathrm{TN}$ & 0.627 & $-19.321 \pm 3.439$ & 0.428 & $-4.343 \pm 0.939$ & -0.934 & $-25.718 \pm 0.658$ & 0.887 \\
\hline & $\mathrm{TE}$ & -0.135 & $70.019 \pm 2.606$ & -0.142 & $0.713 \pm 0.743 \mathrm{~N}$ & 0.751 & $24.430 \pm 0.513$ & 0.865 \\
\hline & BN & 0.031 & $-16.930 \pm 0.938$ & 0.182 & $3.572 \pm 0.330$ & -0.892 & $-9.418 \pm 0.176$ & 0.892 \\
\hline & $\mathrm{BE}$ & 0.629 & $27.525 \pm 2.443$ & 0.456 & $4.677 \pm 0.860$ & -0.747 & $-10.242 \pm 0.457$ & 0.754 \\
\hline \multirow[t]{4}{*}{2014} & $\mathrm{TN}$ & -0.398 & $-16.073 \pm 4.056 \mathrm{~N}$ & -0.378 & $-0.315 \pm 0.662 \mathrm{~N}$ & -0.957 & $-13.812 \pm 0.355$ & 0.923 \\
\hline & $\mathrm{TE}$ & -0.325 & $89.192 \pm 8.073$ & 0.382 & $-2.467 \pm 1.318 \mathrm{~N}$ & 0.960 & $36.866 \pm 0.706$ & 0.951 \\
\hline & BN & 0.168 & $19.186 \pm 1.393$ & 0.612 & $1.599 \pm 0.273$ & 0.880 & $3.745 \pm 0.108$ & 0.908 \\
\hline & $\mathrm{BE}$ & 0.737 & $51.585 \pm 3.338$ & 0.112 & $3.908 \pm 0.654$ & -0.525 & $-3.230 \pm 0.258$ & 0.736 \\
\hline \multirow[t]{4}{*}{ 2011-2014 } & TN & 0.288 & $21.931 \pm 3.437$ & 0.230 & $0.076 \pm 0.010$ & -0.509 & $-12.396 \pm 0.662$ & 0.300 \\
\hline & $\mathrm{TE}$ & 0.215 & $82.783 \pm 4.122$ & 0.019 & $-4.089 \pm 1.217 \mathrm{~N}$ & 0.171 & $15.363 \pm 0.794$ & 0.267 \\
\hline & BN & -0.580 & $-58.147 \pm 1.287$ & 0.004 & $-7.500 \pm 0.498$ & -0.247 & $7.472 \pm 0.243$ & 0.643 \\
\hline & $\mathrm{BE}$ & 0.110 & $-17.370 \pm 2.156$ & 0.332 & $13.635 \pm 8.350$ & -0.463 & $-8.868 \pm 0.407$ & 0.355 \\
\hline
\end{tabular}

Table 4

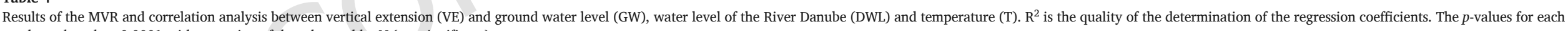
result are less than 0.0001 with exception of data denoted by N (not significant).

\begin{tabular}{|c|c|c|c|c|c|c|c|c|}
\hline Years & Vertical extensometer & GW & & DWL & & $\mathrm{T}$ & & $\mathrm{R}^{2}$ \\
\hline & & Corr. coeff. & $\begin{array}{l}\text { Reg. coeff. } \pm \text { error } \\
{\left[\mathrm{mm} \mathrm{m}^{-1}\right]}\end{array}$ & Corr. coeff. & $\begin{array}{l}\text { Reg. coeff. } \pm \text { error } \\
{\left[\mathrm{mm} \mathrm{m}^{-1}\right]}\end{array}$ & Corr. coeff. & $\begin{array}{l}\text { Reg. coeff. } \pm \text { error } \\
{\left[\mathrm{mm}{ }^{\circ} \mathrm{C}^{-1}\right]}\end{array}$ & \\
\hline 2011 & $\mathrm{VE}$ & -0.974 & $-0.341 \pm 0.008$ & -0.272 & $0.001 \pm 0.000 \mathrm{~N}$ & 0.794 & $-0.015 \pm 0.001$ & 0.962 \\
\hline 2012 & VE & -0.948 & $-0.162 \pm 0.011$ & -0.424 & $0.001 \pm 0.000 \mathrm{~N}$ & 0.929 & $0.017 \pm 0.002$ & 0.924 \\
\hline 2013 & $\mathrm{VE}$ & -0.889 & $-0.148 \pm 0.005$ & -0.618 & $0.013 \pm 0.001$ & 0.527 & $-0.007 \pm 0.001$ & 0.842 \\
\hline 2014 & $\mathrm{VE}$ & -0.722 & $-0.161 \pm 0.017$ & 0.115 & $-0.012 \pm 0.003$ & 0.839 & $0.028 \pm 0.002$ & 0.837 \\
\hline 2011-2014 & $\mathrm{VE}$ & -0.908 & $-0.197 \pm 0.004$ & -0.245 & $0.003 \pm 0.001 \mathrm{~N}$ & 0.704 & $0.005 \pm 0.001$ & 0.831 \\
\hline
\end{tabular}




\section{References}

Agliardi, F., Crosta, G., Zanchi, A., 2001. Structural constraints on deep-seated slope deformation kinematics. Eng. Geol. 59, 83-102.

Alexander, D., Formichi, R., 1993. Tectonic causes of landslides. Earth Surf. Process Landf. 18 (4), 311-338. http://dx.doi.org/10.1002/esp.3290180403.

Angely, M.G., Buma, J., Gasparetto, P., Pasuto, A., 1998. A combined hillslope hydrology/stability model for low-gradient clay slopes in the Italian dolomites. Eng Geol. 49, 1-13.

Applied Geomechanics Inc., 2016. http://www.ampere.com.mx/pdf/Manual_Usuario_Inc_ 722.pdf (Last access 17 Jun 2016)

Bada, G., Horváth, F., Gerner, P., Fejes, I., 1999. Review of the present-day geodynamics of the Pannonian basin: progress and problems. J. Geodyn. 27, 501-527.

Bada, G., Horváth, F., Cloetingh, S., Coblentz, D.D., Tóth, T., 2001. Role of topography induced gravitational stresses in basin inversion: the case study of the Pannonian Basin. Tectonics 20, 343-363.

Bada, G., Szafián, P., Vincze, O., Tóth, T., Fodor, L., Spiess, V., Horváth, F., 2010. Neotektonikai viszonyok a Balaton keleti medencéjében és tágabb környezetében nagyfelbontású szeizmikus mérések alapján (the neotectonic habitat of the eastern part of Lake Balaton and its broader environs: inferences from high-resolution seismic profiling). Földtani Közlöny 140 (4), 367-390 (in Hungarian with English abstract).

Bogaard, T.A., Greco, R., 2016. Landslide hydrology: from hydrology to pore pressure. WIREs Water 3, 439-459. http://dx.doi.org/10.1002/wat2.1126.

Brückl, E., Brunner, F.K., Lang, E., Mertl, S., Müller, M., Stary, U., 2013. The Gradenbach Observatory-monitoring deep-seated gravitational slope deformation by geodetic, hydrological, and seismological methods. Landslides 10, 815-829. http://dx.doi.org/10. 1007/s10346-013-0417-1.

Casagli, N., Rinaldi, M., Gargini, A., Curini, A., 1999. Pore water pressure and streambank stability: results from a monitoring site on the Sieve River, Italy. Earth Surf. Process. Landf. 24, 1095-1114.

Chu-Agor, M.L., Fox, G.A., Cancienne, R.M., Wilso, G.V., 2008. Seepage caused tension failures and erosion undercutting of hillslopes. J. Hydrol. 359, 247-259.

Corsini, A., Pasuto, A., Soldati, M., Zannoni, A., 2005. Field monitoring of the Corvara landslide (Dolomites, Italy) and its relevance for hazard assessment. Geomorphology 66, 149-165. http://dx.doi.org/10.1016/j.geomorph.2004.09.012.

Csontos, L., Magyari, , Van Vliet-Lanoë, B., Musitz, B., 2005. Neotectonics of the Somogy hills (part II): evidence from seismic sections. Tectonophysics 410, 63-80.

Csontos, L., Nagymarosy, A., 1998. The mid-Hungarian line: a zone of repeated tectonic inversions. Tectonophysics $297,51-71$.

Dataqua, 2016. http://www.dataqua.hu/download/adatlap/DA-S-LRB_122_4.pdf (Accessed 17 July 2016).

Directorate of Water Management, 2016. www.vizugy.hu (Accessed 17 July 2016).

Dramis, F., Sorriso-Valvo, M., 1994. Deep-seated gravitational slope deformations, related landslides and tectonics. Eng. Geol. 38, 231-243.

Fabian, M., Kümpel, H.J., 2003. Poroelasticity: observations of anomalous near surface tilt induced by ground water pumping. J. Hydrol. 281 (3), 187-205.

Fodor, L., Bada, G., Csillag, G., Horváth, E., Ruszkiczay-Rüdiger, Zs, Palotás, K., Síkhegyi, F., Timár, G., Cloetingh, S., Horváth, F., 2005. An outline of neotectonic structures and morphotectonics of the western and central Pannonian Basin. Tectonophysics 410, 15-41.

Fox, G.A., Wilson, G.V., Simon, A., Langendoen, E.J., Akay, O., Fuchs, J.W., 2007. Measuring streambank erosion due to ground water seepage: correlation to bank pore water pressure, precipitation and stream stage. Earth Surf. Process. Landf. 32, 1558-1573.

García, A., Hördt, A., Fabian, M., 2010. Landslide monitoring with high resolution tilt measurements at the Dollendorfer Hardt landslide, Germany. Geomorphology 120, 16-25. http://dx.doi.org/10.1016/j.geomorph.2009.09.011.

Guzzetti, F., Peruccacci, S., Rossi, M., Stark, C.P., 2008. The rainfall intensity-duration control of shallow landslides and debris flows: an update. Landslides 5, 3-17. http:// dx.doi.org/10.1007/s10346-007-0112-1.

Horváth, Zs, Scheuer, G., 1976. A dunaföldvári partrogyás mérnökgeológiai vizsgálata. (Engineering-geological investigation of the river bank slide of Dunaföldvár). Földtani Közlöny 106, 425-440 (in Hungarian).

Horváth, F., Bada, G., Windhoffer, G., Csontos, L., Dombrádi, E., 2006. A Pannon-medence jelenkori geodinamikájának atlasza: euro-konform térképsorozat és magyarázó (atlas of the present-day geodynamics of the Pannonian Basin: Euroconform maps with explanatory text). Magyar Geofizika 47, 133-137 (in Hungarian).

Karácsonyi, S., Scheuer, G., 1972. A dunai magaspartok vízföldtani sajátosságai (Hydrogeological properties of high banks along the Danube). Hidrológiai Közlöny 9, 375-383 (in Hungarian with German abstract).

Kleb, B., Schweitzer, F., 2001. A Duna csuszamlásveszélyes magaspartjainak településkörnyezeti hatásvizsgálata. (Assessment of the impact of landslide prone high banks on urban environment along the River Danube). In: Ádám, A., Meskó, A. (Eds.), Földtudományok és a földi folyamatok kockázati tényezői. Bp. MTA, pp. 169-193 (in Hungarian).
Kümpel, H.J., Varga, P., Lehmann, K., Mentes, G., 1996. Ground tilt induced by pumping - preliminary results from the Nagycenk Test Site, Hungary. Acta Geod. Geoph. Hung. 31 (1-2), 67-79.

Kümpel, H.-J., Lehmann, K., Fabian, M., Mentes, G., 2001. Point stability at shallow depths: experience from tilt measurements in the Lower Rhine Embayment, Germany, and implications for high resolution GPS and gravity recordings. Geophys. J. Int. 146, 699-713.

Lehmann, P., Gambazzi, F., Suski, B., Baron, L., Askarinejad, A., Springman, S.M., Holliger, K., Or, D., 2013. Evolution of soil wetting patterns preceding a hydrologically induced landslide inferred from electrical resistivity survey and point measurements of volumetric water content and pore water pressure. Water Resour. Res. 49 (12), 7992-8004. http://dx.doi.org/10.1002/2013WR014560.

Li, P., Zhang, X., Shi, H., 2015. Investigation for the initiation of a loess landslide based on the unsaturated permeability and strength theory. Geoenviron. Disaster. 2, 24.

Lollino, G., Arattano, M., Allasia, P., Giordan, D., 2006. Time response of a landslide to meteorological events. Nat. Hazards Earth Sci. 6, 179-184.

Lóczy, D., Gupta, A., 2007. The Danube: Morphology, Evolution and Environmental Issues. In: Large Rivers: Geomorphology and Management. Whiley, Chichester, pp. 235-260.

Mentes, G., 2003. Local effects disturbing the monitoring of tectonic movements of the mecsekalja fault by shallow deep borehole tiltmeters in Hungary. Acta Geod. Geoph. Hung. 38, 327-335.

Mentes, G., 2004. Investigation of the stability of borehole tiltmeters working in unpacked boreholes inundated with ground water. Acta Geod. Geoph. Hung. 39 (1), 49-54.

2004. Landslide monitoring of loess structures in Dunaföldvár, Hungary. In: Mentes, G. Eperné, I. (Eds.), Geodetic and Geophysical Res. Inst. Hung. Acad. Sci., Sopron, 84. pp.

Mentes, G., 2012. A new borehole wire extensometer with high accuracy and stability for observation of local geodynamic processes. Rev. Sci. Instrum. 83, 015109http://dx. doi.org/10.1063/1.3676652.

Mentes, G., Bódis, V.B., 2012. Relationships between short periodic slope tilt variations and vital processes of the vegetation. J. Appl. Geodesy 6 (2), 83-88. http://dx.doi. org/10.1515/jag-2012-0009.

Mentes, G., Lehmann, K., Varga, P., Kümpel, H.-J., 1996. Some calibration of the Applied Geomechanics Inc. borehole tiltmeter model 722. Acta Geod. Geoph. Hung. 31 (1-2) 79-89.

Mentes, G., Theilen-Willige, B., Papp, G., Síkhegyi, F., Újvári, G., 2009. Investigation of the relationship between subsurface structures and mass movements of the high loess bank along the River Danube in Hungary. J. Geodyn. 47, 130-141. http://dx.doi.org/ 10.1016/j.jog.2008.07.0005

ORIGIN 9.1, 2014. http://www.originlab.com (Accessed 17 July 2016)

Pécsi, M., 1971. Az 1970. évi dunaföldvári földcsuszamlás. (The Dunaföldvár landslide in 1970). Földrajzi Értesítő 20, 233-238 (in Hungarian).

Pécsi, M., Schweitzer, F., Scheuer, G., 1979. Engineering geological and geomorphological investigations of landslides in the loess bluffs along the Danube in the Great Hungarian Plain. Acta Geol. Hung. 22, 327-343.

Pyrus Ltd, 1994. Részletes geotechnikai vizsgálat a dunaföldvári löszmagaspart Hősök tere 20-21. sz. ingatlanok mögötti szakaszára. (Detailed geotechnical investigation of the high loess wall in Dunaföldvár along a section behind the Hősök square 20-21). (11 pp. (with appendix, in Hungarian)).

Rahimi, A., Rahardjo, H., Leong, E.-C., 2010. Effect of hydraulic properties of soil on rainfall-induced slope failure. Eng. Geol. 114, 135-143.

Rapolla, A., Paoletti, V., Secomandi, M., 2010. Seismically-induced landslide susceptibility evaluation: application of a new procedure to the island of Ischia, Campania Region, Southern Italy. Eng. Geol. 114, 10-25.

Rinaldi, M., Casagli, N., Dapporto, S., Gargini, A., 2004. Monitoring and modelling of pore water pressure changes and riverbank stability during flow events. Earth Surf. Process. Landf. 29, 237-254.

Ruszkiczay-Rüdiger, Zs, Fodor, L., Bada, G., Leél-Össy, Sz, Horváth, E., Dunai, T.J., 2005 Quantification of Quaternary vertical movements in the central Pannonian Basin a review of chronologic data along the Danube River, Hungary. Tectonophysics 410, 157-172.

Scheuer, G., 1979. A dunai magaspartok mérnökgeológiai vizsgálata (Engineering geological investigation of the high banks of the Danube). Földtani Közlöny 109, 230-254 (in Hungarian with German abstract).

Schnellmann, R., Busslinger, M., Schneider, H.R., Rahardjo, H., 2010. Effect of rising water table in an unsaturated slope. Eng. Geol. 114, 71-83.

Schweitzer, F., Juhász, , Szilárd, J., 1978. Magyarország felszínmozgásos területeinek földtani és múszaki katasztere. (Geological and technological cadaster of the surface-motion areas of Hungary). Hungarian Geological Institute, 22 (in Hungarian).

Síkhegyi, F., 2002. Active Structural Evolution of the Western and Central Parts of the Pannonian Basin: a Geomorphological Approach. vol. 3. EGU Stephan Mueller Specia Publication Series, 203-216.

Springman, S.M., Thielen, A., Kienzler, P., Friedel, S., 2013. A long-term field study for the investigation of rainfall-induced landslides. Geotechnique 63 (14), 1177-1193. http: //dx.doi.org/10.1680/geot.11.P.142.

Szabó, J., 2001. A csuszamlásos folyamatok szerepe a magyarországi felszínformák kialakulásában (Role of sliding processes in development of the Hungarian surface features). In: Ádám, A., Meskó, A. (Eds.), Földtudományok és a földi folyamatok kockázati tényezói. Bp. MTA, pp. 143-168 (in Hungarian)

Uhlemann, S., Smith, A., Chambers, J., Dixon, N., Dijkstra, T., Haslam, E., Meldrum, P. Merritt, A. Gunn, D. Mackay, J., 2016. Assessment of 
ground-based monitoring techniques applied to landslide investigations. Geomorphology 253, 438-451. http://dx.doi.org/10.1016/j.geomorph.2015.10.027.
Wilson, G.V., Periketi, R.K., Fox, G.A., Dabney, S.M., Shields, F.D., Cullum, R.F., 2007. Soil properties controlling seepage erosion contributions to streambank failure. Earth Surf. Process. Landf. 32, 447-459. 